\title{
The doctor speaks
}

James A. Elmore, MD

Neurology ${ }^{\circledR}$ 2018;91:418-420. doi:10.1212/WNL.0000000000006074

The claustrophobic intimacy of an ER exam room can test the dearest relationships. Back home in the big old house, there is space for Elizabeth and daughters Julie and Anne to spread out. That freedom of movement is one thing that is missing here. Another is the sitter, who is with Elizabeth all day long and who serves as a buffer when Anne and Julie visit. Dismissed by Julie before the EMS arrived, she plays many roles.

If left alone, Elizabeth wanders about the house and gets lost. The sitter corrals her in the recliner in front of a TV which, though mostly ignored, is a soundtrack to her stream of consciousness and pleasant memories. Without it, there would be silence.

Unlike some of us, Elizabeth cannot tolerate silence. That's another reason there is a sitter: to give her someone to talk to, a substitute for an absent spouse.

Elizabeth needs that kind of attention now.

There is a knock on the door. It is the polite Dr. Ellis, who always knocks. He must have been around the corner seeing another patient to have gotten here so quickly, or maybe there is some other rational explanation for his rapid arrival. He's having trouble entering the tiny room because the nurse, preoccupied with the tasks of documentation, blocks the door.

This gives Julie the chance to take charge. She will orchestrate things with the minimum discomfort to Elizabeth. She gently moves the nurse to one side, gets her other hand on the door before Dr. Ellis can get a foot in, and has him back out in the hallway where he accedes to Julie's buttonholing manner while pressing ahead with his routine introduction.

"Hi, I'm Dr. Ellis. I'm..."

"I know. You saw Mother when she had her first stroke."

“Oh?”

“I don't expect you to remember. It was at St. Jo's 14 years ago. I think Anne brought her to your office once after that. Then, Dad took over. She's done well until today."

He shakes his head up and down, though he hasn't taken in all that Julie has said. He is clearly relieved to be dealing with someone informed and rational rather than the usual overwrought family.

"I'm so glad you're here and not someone we don't know. We want the best for Mother, but... you're the doctor. We'll do whatever you recommend."

That's an ingratiating first thing to say. Like most doctors, Ellis is so jaded that he suspects a little irony and, perhaps, manipulation in it. At least he's more at ease now that his authority has been superficially established, and more important, he will do his best to live up to Julie's flattery.

"Okay, tell me what happened."
Correspondence

Dr. Elmore

jelmore01@charter.net

MORE ONLINE

ค Audio

Listen to Dr. Elmore read this story.

NPub.org/tk6tc9 
"The sitter said she got confused and dropped her afternoon cup of tea out of her left hand at about 4 o'clock. I've been with her for an hour now. The symptoms seem to come and go. Sometimes her speech is clear, and sometimes it's slurred, and when we first got here, the left side of her face drooped, but not now."

“That's not consistent with an embolic stroke even though she has atrial fibrillation. Too much fluctuation. Is she taking the Coumadin regularly?”

"Like clockwork, every day at 6 PM. Dad always made sure her INR was at least 3 . He obsessed about it. He really got upset if it was less. He said she needed it higher than average."

The questions stop. A piece clicks into place.

"Dr. Jordan is...was...her husband."

"Yes. And I'm their daughter, Julie."

He doesn't remember everything just yet.

"We'd better get on with things. Like they say, time is brain."

Dr. Ellis finds very little new deficit on exam. tPA is excluded because of the elevated but still subtherapeutic protime.

He thinks that a 90-year-old woman is not really a candidate to be flown to Atlanta for an emergency embolectomy, even if he thought she had an embolus, which he doesn't. He says that the simplest thing would be to admit Elizabeth to the hospital for observation and rehab.

He shouldn't rest on his laurels just yet. If he stops here, he's going to miss something.

Julie repeats, "You're the doctor. We'll do whatever you recommend."

He wonders if Julie wants everything done, or if she wants only comfort measures.

He is unsure enough to go the extra mile and order a CTA to rule out an embolus. There's very little chance of harm, and the reassurance will be worth the tiny risk. He will be back after he's reviewed the test.

"We'll do whatever you recommend."

Don't overdo it, Julie.

At a physician workstation, he reviews his patient list for anything that might be pending. It is $6 \mathrm{PM}$ and he's ready to go home. It turns out that the CTA is the only thing keeping him.
While he's waiting, he has time to think about Dr. William Jordan.

When he first joined the neurology group many years ago, there were still some primary care physicians who called to communicate personally the reason for referral. With so many other ways of conveying that information now, he thinks it antiquated. But it gave them a chance to become familiar with the new specialist and establish a connection that might prove useful later on.

Most referring doctors were loquacious, with empty pleasantries or questions asked in search of common bonds: colleges, medical schools, and colleagues. There had been none of that. Even the introduction was spare. "This is Jordan, down in Sparta." Those few words struck him as humble and refreshingly simple.

Ellis smiles as he checks the radiology imaging system. Scrolling through the images, he slows down and does a double take. There is an unmistakable void in the right MCA. He worries that it might be psychologically traumatic to airlift a frail old woman. On the other hand, it could save her from a devastating stroke.

\section{You're the doctor. We'll do whatever you recommend.}

He picks up the phone and fortunately gets a radiologist who is willing to talk to him.

"It looks like a big clot, but there is really good collateral flow. Does she have much deficit?"

“No, but it's fluctuating."

"That might indicate a thrombus that could propagate."

"I'll call Grady and see what they say."

The endovascular specialist listens patiently. The story tells itself. 90? "Really?" the tone in her voice seems to say. The specialist will review the images and call back.

In the exam room, the walls seem a little closer together; the ceiling a little lower. Maybe Elizabeth's speech is the slightest bit thicker. He does his best to make any intervention seem futile. They all shake their heads. They seem to understand. He looks at Elizabeth, sure that she will refuse the airlift, but instead she says, "You're the doctor. We'll do whatever you recommend." He thinks she might be simply echoing Julie's words. He looks for guidance to Julie, who smiles and shakes her head.

"I'll let you know what the doctor in Atlanta says."

The workstation is quiet. No distractions. The heavy silence returns him to sick rooms where patients wait for the 
diagnosis, wait for treatment, wait in acceptance of whatever fate holds in store.

He had knocked on the door, not expecting a reply, just announcing his presence. The room was clean, uncluttered with any personal effects, flowers, or cards. No electronic devices. The TV screen was black. The lights were off. A few rays of sun penetrated the closed blinds and diffused through the room to produce a luminous dusk. Other than the click of the door latch catching behind him, there was no sound.

The patient's hair was snow white. The wrinkled face appeared relaxed.

Ellis walked to the side of the bed. A sense of déjà vu was strong. He recognized this tableau. The weary traveler looks down the tracks for any sign of an approaching train, waiting for the one that will stop and take him on board.

Before his thoughts went too far, he decided to get on with the business at hand. He reached out, touched the patient's shoulder, and said, "Dr. Jordan."

The eyes opened without startle.

"How are you feeling?"

"As well as I can expect."

He had been admitted for pneumonia, caused by difficulty swallowing and shallow breathing. The myasthenia gravis had become increasingly difficult to manage, and eventually complications would prove fatal. One of Dr. Ellis' associates was the attending, and Ellis was covering the hospital that day.

It was a brief, unexceptional encounter. Ellis was busy. The patient clearly would have preferred to resume his repose. He seemed disinclined to speak, taciturn as was his nature.

"Is there anything that you need?"

"No."

"Well, good day."

Almost out the door, Ellis' escape was arrested by, "One thing."

Ellis can't quite recall what was said. He vaguely remembers a medication request.

"Okay. I'll order it."

Before he can dredge up any further memories, the return call from Atlanta interrupts his thoughts. The endovascular specialist gives her opinion of the CTA.
"Do you think it's worth going after the clot?"

"If she were younger, I would say definitely go for it. But, given her age and the paucity of deficits, I think we could do more harm than good. I would fill her tank with fluids, let her BP run on the high side, and watch her in the ICU. If she deteriorates, we've got a bed waiting for her here. You think the family will be okay with that?"

"I think they'll be happy to stay here."

Ellis sighs with relief and, in something like a trance, says, "Heparin."

"Pardon me; I didn't get that."

Heparin. It had seemed an odd thing to ask for. Assuming he was talking about the standard DVT prophylaxis for someone immobilized in bed, Ellis had asked, "Haven't you been receiving the injections?" The patient said nothing more and closed his eyes, resuming that waiting pose.

"What about starting heparin?"

"Heparin? Ordinarily, we no longer recommend its use in acute stroke, but in this circumstance, yes, that might help prevent any new clots while you're increasing her Coumadin dose."

In the exam room, everyone is talking.

"Mother, please be quiet a moment and let Dr. Ellis get a word in."

"Well, I'm feeling so much better that I just don't see any reason to bother these nice people here anymore. But, of course, you're right. I'll let the doctor speak.”

"The specialist in Atlanta thinks you should stay here. We've started a heparin drip until your protime is therapeutic. And, we'll need to keep an eye on your blood pressure."

"Whatever you say; you're the doctor."

"Thank you for your efforts, Dr. Ellis. We know Mother is in good hands.”

"I have that feeling, as well...I'll see you tomorrow."

Elizabeth calls out, "One thing."

Déjà vu strikes as Ellis turns back from the door.

"Bill says thank you, too."

Elizabeth, my dearest, you read my mind. 


\section{Neurology}

The doctor speaks

James A. Elmore

Neurology 2018;91;418-420

DOI 10.1212/WNL.0000000000006074

\section{This information is current as of August 27, 2018}

\section{Updated Information \& Services}

Subspecialty Collections

Permissions \& Licensing

Reprints including high resolution figures, can be found at: http://n.neurology.org/content/91/9/418.full

This article, along with others on similar topics, appears in the following collection(s):

All Cerebrovascular disease/Stroke

http://n.neurology.org/cgi/collection/all_cerebrovascular_disease_strok e

All Clinical Neurology

http://n.neurology.org/cgi/collection/all_clinical_neurology

Information about reproducing this article in parts (figures,tables) or in its entirety can be found online at:

http://www.neurology.org/about/about_the_journal\#permissions

Information about ordering reprints can be found online:

http://n.neurology.org/subscribers/advertise

Neurology ${ }^{\circledR}$ is the official journal of the American Academy of Neurology. Published continuously since 1951, it is now a weekly with 48 issues per year. Copyright (O 2018 American Academy of Neurology. All rights reserved. Print ISSN: 0028-3878. Online ISSN: 1526-632X.

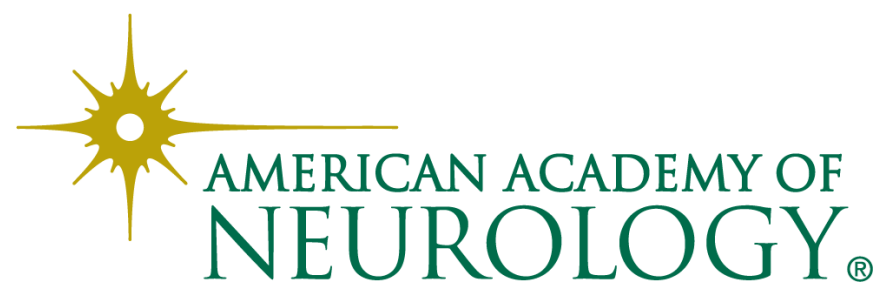

